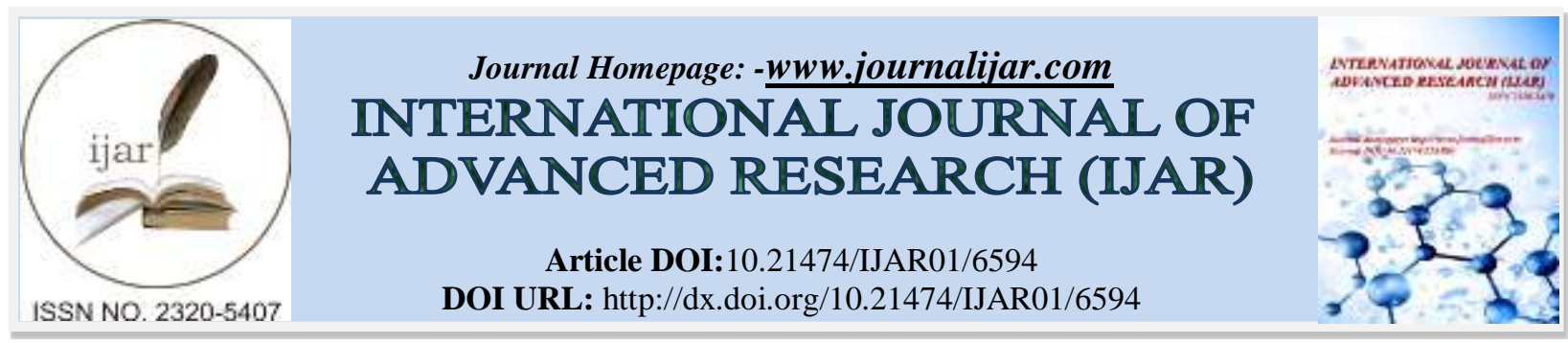

RESEARCH ARTICLE

\title{
RISE OF ASIA: A CREDIBLE CHALLENGE TO THE HEGEMONY OF THE UNITED STATES IN INTERNATIONAL ORDER?
}

Umme Salma Tarin.

Lecturer, Department of International Relations, Bangladesh University of Professionals.

\section{Manuscript Info}

Manuscript History

Received: 20 December 2017

Final Accepted: 22 January 2018

Published: February 2018

Keywords:-

Rise of China, India, Global

Governance, Asia Pacific Rebalancing, Hegemony.

\begin{abstract}
The United States emerged as one of the most powerful nations in the world during the transition from the 19th to the 20th century. The U.S. succeeded the United Kingdom as the worldwide hegemon after the Second World War. Numerous International Relations scholars suggested that 1945 was the starting of a cycle in which the United States would rise as a worldwide hegemon and shape the world politics. These researchers also theorized that the U.S. will eventually drop and lose its status as hegemonic ruler of the world system. Thus what remains to be seen is which country will evolve as the world hegemon after the United States? Which country will be able to overcome the gains that the U.S. has made and obtain a legitimate position of dominance recognized by the other great powers? Various researchers anticipate China will be the next hegemon. A few see Russia as a resurgent power. Still others anticipate that India will rise as the world hegemon, while a few accept that the European Union will be able to overwhelm the U.S. This paper will discuss what are the possibilities that China or India might truly challenge the U.S. hegemony and what are the variations in western perception regarding the rise of China and India and the threat or opportunities that they pose to the United States.
\end{abstract}

Copy Right, IJAR, 2018,. All rights reserved.

\section{Introduction:-}

Problem statement: -

Many shifts in the international system accompanied the end of the Cold War. Among these the most significant and noticeable has been the dominance of the United States as the most powerful state in the world. The presence of USA has been very much visible in many regions outside the American continent and most of the time this presence was accompanied by its European friends. This presence as a whole has been referred to as the hegemony or dominance of west in the international order. In general, IR scholars agree that international order refers to the structure, functioning, and nature of the international political system. The term is useful for describing the broad pattern of interactions among states. So, in the nature of the political system and the broad nature of interactions of states certainly the West has been playing a central role. In case of political decision making, military deployment, economic activities, everywhere the governance seems to be run and represented mostly by the Western powerful nations. But in recent years the radical transformations that have been taking place in the field of political, strategic and economic powers of the Asian states have bound the scholars of this discipline to discuss a lot about the 
consequences this transformation can bring about. The Rise of Asia or the Asian Century are most common labels used for defining the ever increasing nature of growth the Asian countries like China, India or Japan have been experiencing in all spheres - political, military and strategic. Among the Asian powers China and India deserve special attention considering the size, population, nature of political structure, influence over international strategic relations and their nature as regional hegemons. These countries are constantly gaining control over vast resources, they have influence over the whole region but it is not clear what is their intention regarding becoming a global hegemonic power that will be a challenge to the existing nature of international order primarily dominated by West. The Asian century which is considered to parallel the characterization of the $20^{\text {th }}$ century as American century and before that $19^{\text {th }}$ century as the British century, has grabbed the attention of the world from many aspects. There have been many debates in this field and many are yet to come. Huge number of research is being carried out to understand the rise of China and India, the nature of the intention each country has in case of their regional role playing and how such rise of these countries especially China is threatening U.S.'s presence as a regional balancer in the Asia-pacific region, but little focus has been given on the issue what is the actual intention of these countries (China and India) in case of projecting their increasing power at a global level against West, especially the United States. There are people who argue that the peaceful rise of China does not have any intention to compete American hegemony in the political, strategic and economic level in a global perspective; but there are others who argue that China's rise is primarily to contain US presence in Asia Pacific region and gradually it will cut US's global position in multiple ways. In case of India the arguments mostly flows surrounding the notion that being at good terms with USA in her strategic relationship, India has been a protector of US interest in the Asia-pacific region and it will not destabilize the balance that US has been maintaining as an outside power as this serves the interest of India in the first place; but curiosity remains in understanding India's intention in playing a global role challenging an existing hegemon when one goes through the strategic culture of the Indian state where projection of India as a powerful and dominant nation has been the centre of Indian diplomacy.

On the other hand, the role China and India play in other aspects of global governance like: issues of human rights, poverty reduction, trade balances, income inequality etc. is largely unexplored. Whether China and India will come out of their historical legacies of involving themselves with the issues of the Third World and can earn the legitimacy of playing a global role is still not very clear.

The central focus of the paper is exploring these areas: First, what are the real intentions of China and India during an Asian Century? Second, do China and India can actually have the potential capabilities to challenge and cut the role of the exiting global hegemonic force? The rise of China and India is not myth, but there are questions whether the rise of these countries has the potential to blow the hegemony of US away drastically in the coming decades or the rise will have implications only on a regional scale or on economic aspects.

\section{Central research questions:-}

The research will mainly focus on answering two questions:

First, Is China truly a hegemonic challenger that can replace the United States?

Second, Is India a challenger to the hegemonic status of the United States, and why does not the rise of India raise same level of concern among the western scholars as the rise of China does to them?

\section{Literature review:-}

During last few decades India and China have become key players in world stage with huge economic success. These are two nations which represent one-third of all people living on the planet and that aspect is needed to be noted. In the 17 th century, China and India accounted for more than half the world's economic output. After a modest interlude, the pendulum is swinging back to them at a speed the West has not grasped (Cohen, Roger, The Baton Passes to Asia). China, from 1978 to present, has seen record economic growth, achieving an average annual growth rate of 8 percent. India has overcome the - Hindu rate of growth\| that plagued its economy between 1950 and the late 1980s and now maintains steady growth of six percent annually, with growth in recent years between nine and ten percent. They are the world's second and third largest economies and are the world's quickest developing economies as well; both are anticipated to surpass the United States as the world's leading financial powerhouses during last half of this century. 


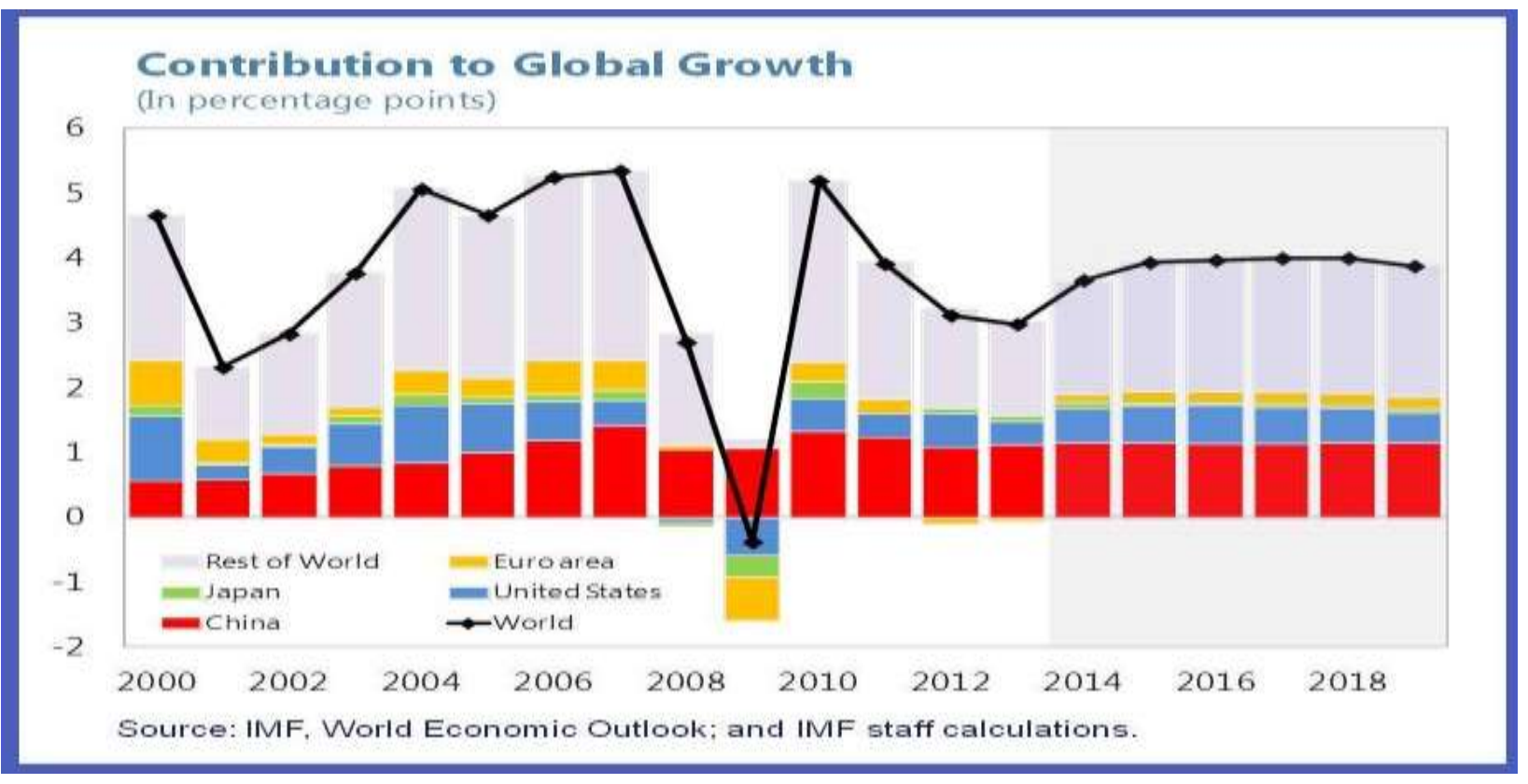

Militarily, both China and India are developing in quality and impact inside the Asian circle, and China in specific is seen as a risk to U.S. dominance in the Asia Pacific region. India is, on the other hand, not seen as much of a risk to the U.S. military - without a doubt it appears that the United States has as of late been looking for to make India a vital accomplice to balance and conceivably contain Chinese military control. "India's military capabilities are presently more reasonably seen for what they are: constrained but profoundly proficient, and in this way competent of significant growth. Both India and the United States keep a watchful eye on China. The moderate military buildup of Chinese powers, coupled with rising military investing as a rate of their evergrowing GDP, has frightened numerous observers in the U.S. and been the subject of much insightful dialogue.

Amitav Acharya's (2011) article on "Can Asia Lead? Power ambitions and global governance in the twenty first century" mainly focuses on Asian powers' standpoint in global governance. He emphasized that although Asian conception of international relations are confined within the domain of self-help, largely following the realist paradigm of international relations; and there will be a long way to go if China or India decides to have a prominent role in global governance which requires showing larger arena of attention other than self-help. They need to reduce the gap between national aspirations and their contribution as global leaders. However, the article does not focus on the political and strategic aspects of Asia's rise and its consequences. In describing China's role in the emerging world order Hans J. Giessmann (2006) recognized that China is no more an economic power rather there are particular motives behind Chinese foreign policy. By focusing on the strategic aspects he also tries to identify the self-contrasting nature of Chinese role in world politics. Improvement in China's relationship with the European countries might point on Chinese intention to become a active player in international politics. John J. Mearsheimer (2010), in his article named "The Gathering Storm: China's Challenge to US Power in Asia" explores the trajectories of China's power ambition covered behind their policy of peaceful rise. The article mainly concentrates on the Asia-pacific region where the rise of China is surely bringing changes in the balance of power', hence US will no longer be the preponderant power in the Asia-Pacific region. Jochen Steinhilber (2006) in his article on "China: A new actor in the Middle East and North Africa Region?" explores how China's interest in North Africa and Middle East continue to grow with their rising need for energy. China is at the same time working on the way to establish their political and economic presence in those regions. By actively pursuing their goal of securing access to sufficient energy resources abroad, China is expanding their area of influence. China will be trying hard to place its diplomatic relationships with the Middle Eastern countries where US continues to dominate until now. Robert Kagan, a fellow at the Brookings Institution wrote in his essay named "Not Fade Away: The Myth of American Decline" in The New Republic that US primacy is undiminished and that Americans, as long as they set their minds to it, are poised to sit atop the global pecking order for the indefinite future. He acknowledges the rise of India, China and other nations, but maintains that only China will compromise US interests and other countries including India will either align with US or remain on the geopolitical sidelines. Umme Salma Bava (2007) underscores the 
changed dynamics of Indian foreign policy throughout last decade where India appears to be shaping a new future for itself. India's emerging economic status along with its redefined self -image at the global level is leading towards a new political role played by India at different levels. Pang Zhongying (2007) discusses China's intention and capacity to contribute to global governance. Putting overriding influence on economic growth might have constrained China's capacity to play a role in global governance.

There has been development of ideas relating to this topic for a significant period of time. There have been writings focusing particularly on India's economic rise, or china's economic rise, Rise of Asian Powers as a whole, China's views regarding US's presence in the Asia Pacific region etc. There are limitations in this field of research with regard to the facts that: 1) most of the works ignore India's intention to become a global power which can cut US's dominance if it wants to. India is supposedly America's newest strategic partner. Relations have certainly improved since the 2005 agreement on civilian nuclear cooperation, but on many other fronts, Washington and New Delhi differs 2) Understanding both China and India's rise at the same time from a politico-strategic-economic perspective and counting its consequences for the exiting western dominance is not carried out properly. China is now in the midst of fashioning geopolitical aspirations that match its economic strength and the same is true for India. Bipolarity no longer constrains how far nations--even those aligned with Washington--will drift away from the fold. United States no longer exert the economic influence that it once did; 3) Most of the literature highlight on the challenges China or the rise of Asia as a whole is posing to the west's hegemony in international system, without discussing it properly whether these countries are actually capable of taking up this challenge or not. So, understanding the projection of defensive-offensive dilemma of the military development of these countries is an issue of critical importance to carry out research on.

\section{Research Design and Methodology:-}

The research will be primarily a qualitative analytical study. Different theoretical approaches of International Relations will be used as tools of analysis to carry out the research.

Methods of data collection:

Primary data collection:-

This will be mainly conducted by interviews. Face to face, telephonic and email interview techniques will be followed. Interviews will be taken from experts, diplomats, policy making bodies, government officials of concerned ministries and from concerned individuals.

\section{Secondary data collection:-}

Secondary data will be collected from books, on-line resources, newspapers, journals, magazines and other documents available on the research topic.

\section{Key Arguments:-}

China is an exceptionally capable military force inside the Asian circle and this is a calculation that cannot be neglected when speaking of advantages in seeking global hegemony. The People's Liberation Army fought the United States on the Korean Peninsula in the 1950s, and has maintained absolute control over a very large geographical area for the last sixty years. China has the most striking potential to compete militarily with the United States and has field disruptive military tech that could over time offset traditional US military advantages. Figures that state China's military has the potential to challenge any other state inside the Asian region. The United States government has tirelessly followed China's investing on military development and advancement and to a few examiners and top authorities at the Pentagon - the numbers are disturbing. 


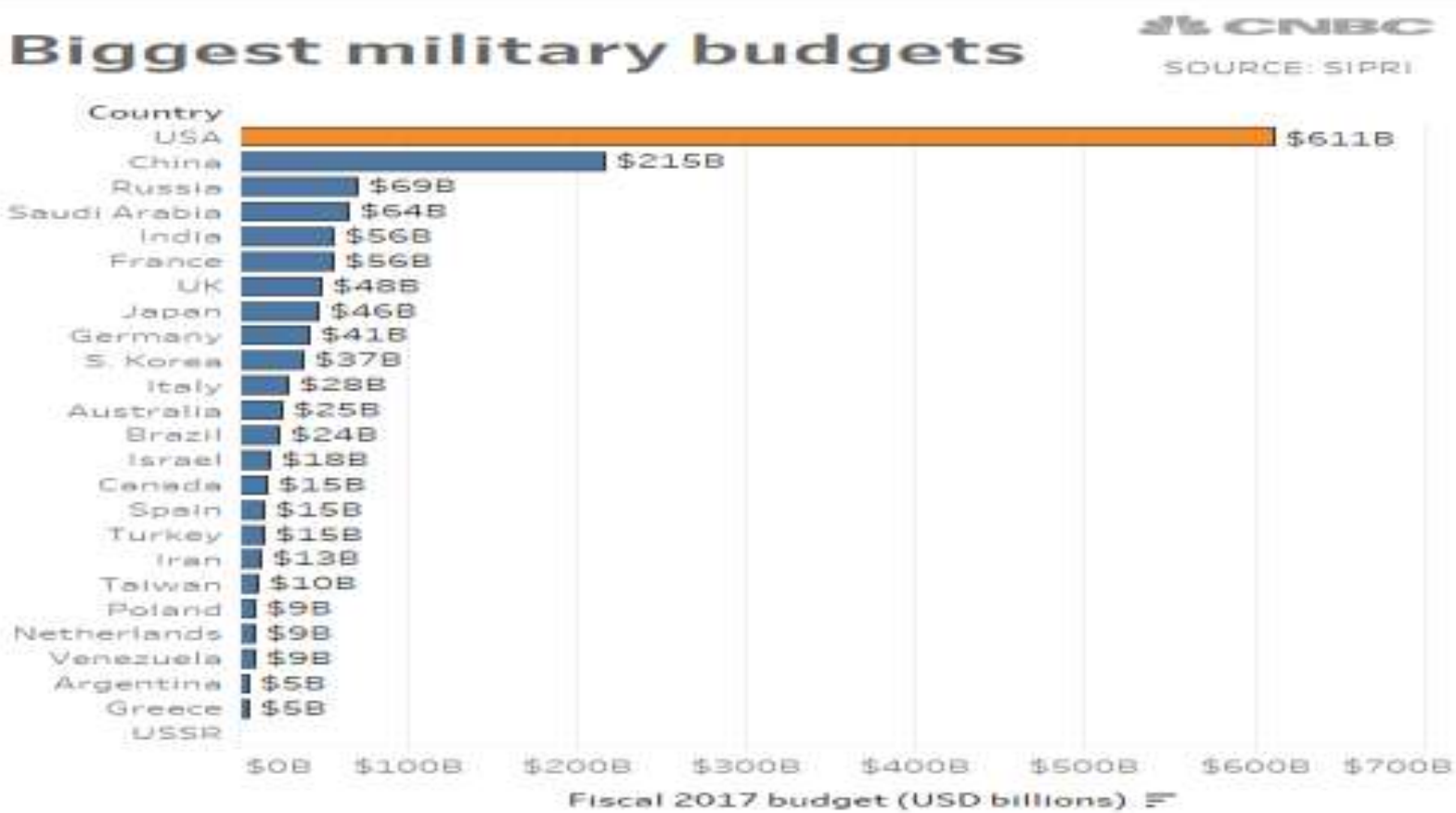

One of the extraordinary qualities of the Chinese military, and of the Chinese nation in general, has continuously been its huge populace. In the twentieth century, China was able to utilize this populace to fulfil the needs of the worldwide economy by providing cheap labour to the multinational organizations of the world. These patterns have driven China's development for a long time.

\section{China's annual GDP growth}

(Unit: percent, year-on-year)

14

Projected at

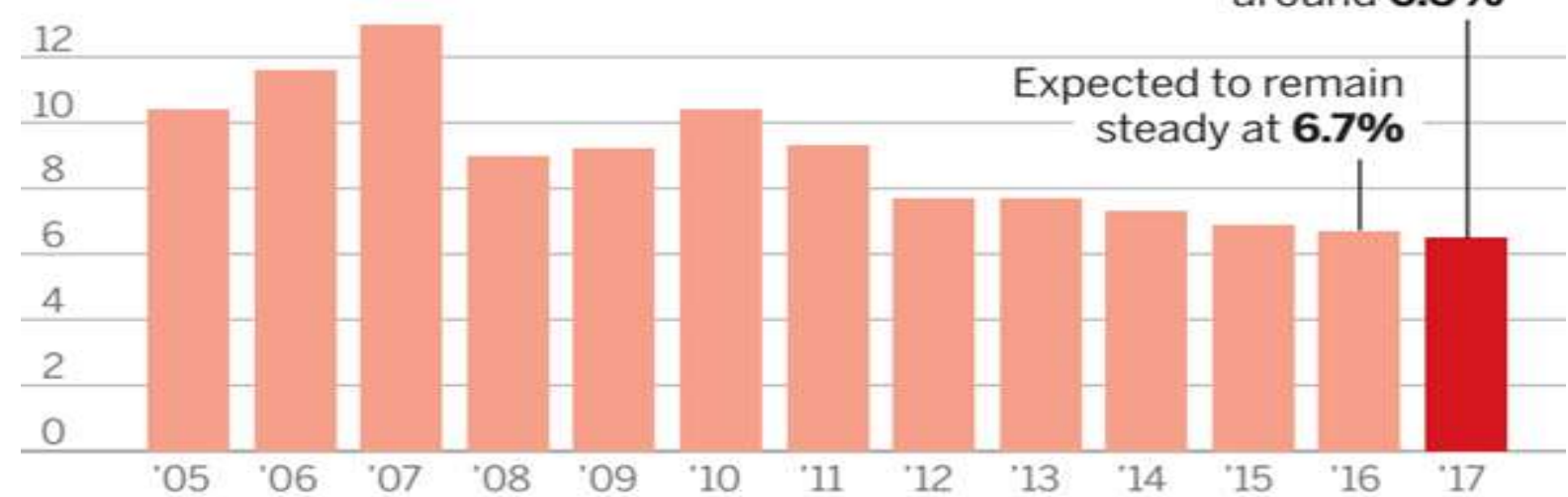

Sources: National Bureau of Statistics. Chinese Acaderny of Social Sciences

CHINA DAILY

A last financial advantage that China keeps up that will permit it to compete at the universal level in the next fifty a long time, and that may posture a risk to U.S. authority, is the tight control that the Communist Party holds over data and media inside the nation. Whether or not the Chinese Communist Party will permit society to gotten to be more open, and possibly equitable, remains to be seen, but at display it shows up that China is certainly able of keeping up tight control over data inside its borders while moreover permitting capitalism and a generally free economy to thrive. 
When considering the rise of China, we must be cautious not to exaggerate the significance of financial matters since it is misleading to calculate victory simply in terms of financial development rates, particularly as it is farfetched whether they can be anticipated more than a few a long time into the future. Much of China's potential success in the future, as seen in the advantages listed above, relies heavily on the economic success that it has experienced over the last three decades. Extrapolating that China will certainly achieve the status of international hegemon by 2030 because it has enjoyed economic success since 1980 is similar to the erroneous argument — much lauded throughout the 1980 s — that Japan would soon rise to hegemonic status. Hence, we must too consider the boundaries that exist to square China from accomplishing its objective and rising to preeminent status on the world system. Political and social suppression is an issue that is inseparably tied to frail democratic institutions inside China. China's Communist Party recognizes the dangers that contradicting voices posture to it, but another thing that the Party individuals are mindful of is that a generally closed society contributes to the dissatisfaction of different groups. The CCP keeps up an oppressive society characterized by low levels of participation in democratic institutions, high levels of repressed speech, a highly censored press, and permits people to assemble and worship only with a license from the government. Democracy could offer Chinese citizens the opportunity to express their thoughts approximately administration as voters and candidates inside the framework. Talk about and dialogue encompassing democratic decisions and other capacities of democracy could moreover contribute to capacity of citizens to discharge their dissatisfaction and express their true blue thoughts around society, the government, and the state. Dissatisfaction emerges when bunches are especially irresolute toward the Communist government and in some cases as it were wish to lock in in exchange and have their voice listened. But when the government sees a bigger risk than really exists in reality and authorities blow up and curb bunches concurring to those misperceptions, bunches start to endeavour indeed harder to guarantee that their voices are listened and to contradict the administration.

Besides the above explained case, that depicts political and social impediments obstructing China's way to authority, an aging population that is set to increase rapidly over the course of the next twenty years will have a negative impact on financial development, as well. China may not be able to preserve the financial quality that has permitted such quick advance over the final twenty years since of the increasing number of aged people who will grow older will and require support from others in the coming years. China's capacity to preserve a solid financial position is imperative to its capacity to construct military control and use impact all through Asia and the rest of the world. A maturing populace hence gets to be a potential detour to Chinese authority in the event that it prevents financial growth.

Making a case for Indian hegemony is almost similar to making the case for China since it is too a nation far away from Europe, and a country that has continuously kept up an exceptionally sprawling population. India, like China, has picked up acknowledgment as a financial powerhouse in later years, and shows up prepared to use those financial achievements into social, political, and military preferences that will permit it to work out more noteworthy control amid the 21st century. In fact, in terms of estimate considering geography, population, military capability, and potential for financial development, India is the only country that can match China. In fact, it has far better demographics mean that the population is likely to be bigger than China's by 2030. The preferences that India has in looking for hegemony are comparable to those of China. India is right now less urbanized than China, at somewhat less than $30 \%$. Free speech, a free press, and the assemble and express dissents, are rights that Indians appreciate and practice. Westerners feel a profound regard and sympathy for the non-violence practiced by both the Dalai Lama and India's most celebrated legend, Mahatma Gandhi. Indian culture and values and an open society create appeals to Westerners. Western culture holds Gandhi up as an illustration of perfect way or the most perfect way to challenge treachery and to look for alter.

The U.S. is doubtful of China's benevolent intentions in developing military power, but in the case of India the U.S. appears arranged to acknowledge them as a vital accomplice that can offer assistance to watch the Asian region, increment security in the area, and conceivably give a counterweight to China.

Developing military interaction between the U.S. and India has also implied an upward drift in business interactions. India's financial development spurt has pulled in firm American corporate intrigued and American companies presently contain a critical India lobby in Washington. India's capacity to develop financial ties with Washington will doubtlessly affect its capacity to seek after hegemonic status amid the 21st 
century. Investigators extend that in the event that India is able to preserve later development rates of eight percent, and ended up more closely connected to the U.S. economy, India will hence have ended up the quickest developing economy out of 34 emerged and developed markets and the world's third biggest economy by 2020. Finally, one of the most vital components dragging down the prospect of Indian authority is the gigantic number of Indians living in destitution and the caste framework that endures in numerous parts of the nation, hampering social interaction and social portability.

\section{Central Research Findings:-}

Though China has reliably outpaced India in terms of financial development for the last more than thirty years and does have a marginally bigger populace, the two nations are quite evenly matched relative to one another. Thus, it seems odd that the perceived threat of Chinese hegemony is so high and the threat of an Indian hegemony is disregarded. Is it that India is not a danger? Or is it that neither of the nations is a risk but Western discernments and character have made a foe where none really exists?

It is still a matter of scepticism either India or China has the capacity to reach the status of hegemon amid the next century. Neither India nor China will challenge U.S. authority inside the next century for a few key reasons. U.S. military might is too far advanced in terms of technology and funding for any nation to challenge it in a conventional war. It would take an unimaginable catastrophe to wipe out the military control of the United States and hence remove the current hegemon. From a realist point of view, the U.S. will be able to preserve a hold on authority well into the future based on the quality of its military power and control over global governance.

An alternative perspective might contend that it may be conceivable for China or India to challenge the United States in financial terms since a U.S. financial crisis could possibly crush the might of the United States economy. This contention should not be exaggerated, because of the issues regarding both the Chinese and Indian economy discussed above. But, in spite of the fact that China or India may start to have a higher GDP than the U.S. during the next twenty to thirty years, the worldwide economy is so dependent on the success of the U.S. economy, and the U.S. economy is so profoundly entwined inside the universal framework, that it would be exceptionally troublesome to replace. The U.S. economy is exceptionally differing, broad-based in such a way that totally dislodging the U.S. from its part as the world's driving financial control would really take numerous decades to accomplish.

At last, returning to a constructivist point of view, it will be exceptionally troublesome for China to replace the United States as hegemon since of Western identities and ideologies that are dug in inside the universal framework set up in the 20th century and are extended further by U.S. dominance. The West, especially the United States, sees China as a remaining bastion of Communism that cannot be trusted. Numerous Americans still see China as "other", compared to the Western "us." India is a democratic country and Americans and other citizens of western countries generally appreciate India's quality as the world's largest democracy. This means that if India were able to rise up and become a hegemonic challenger, most of the world, both democratic and non-democratic nations, will perceive Indian hegemony as the legitimate successor to the international norms established over the past three hundred years by British and American hegemony. Moreover, India has pursued the previous Third World nations, with at least as much success as China, and ought to be able to utilize their alignment with, and already fruitful authority inside the Third World as a political advantage.

Despite India's advantage over China and the consistent development of both countries, discernments stay vital and the view in the West that India and China remain inferior to the more-civilized Western nations that once dominated the Asian region will have to change soon as either can really end up as a strong hegemonic pole. Whether or not India and China achieve the position of global superpower, the United States will require to pick up a more profound understanding of Asia in the coming decades. 


\section{Bibliography:-}

1. Mearsheimer, John J, 2010, "The Gathering Storm: China's Challenge to US Power in Asia", Chinese Journal of International Politics, Vol. 3, No. 4, pp. 381-396

2. Giessmann, Hans J., 2006, "New Powers for Global Change: China's Role in the Emerging World Order", Briefing Paper, FES Beijing.

3. Bava, Umme Salma, 2007, "New Powers for Global Change: India's Role in the Emerging World Order", Briefing Paper, FES Beijing.

4. Acharya, Amitav, 2011, "Can Asia Lead? Power ambitions and global governance in the twenty first century", International Affairs, Vol. 87, No. 4, pp. 851-869

5. Kaplan, Robert D., 2012, The Revenge of Geography: What the Map Tells Us About Coming Conflicts and the Battle Against Fate, Random House Trade Paperbacks, USA

6. Mearsheimer, John J, 2001, The Tragedy of Great Power Politics, W. W. Norton \& Company, USA

7. Bajoria, Jayshree. "Inequalities in Asia's Giants." Backgrounder (2007). 22 Mar. 2008 <http://www.cfr.org/publication/14706/inequalities_in_asias_giants.html>.

8. BBC World Service. "China Warns Against U.S. Hegemony." BBC News 17 July 2001. 20 Mar. 2008 <http://news.bbc.co.uk/2/hi/asia-pacific/1439633.stm>.

9. Bedi, Rahul. "U.S.-India Defence Deal to 'Counter China'" Telegraph 26 Feb. 2008. 16 Mar. 2008 $<$ http://www.telegraph.co.uk/news/worldnews/1579938/US-India-defence-deal-\%27to-counterChina\%27.html .

10. Betts, Richard K. "A Disciplined Defense: How to Regain Strategic Solvency." Foreign Affairs (2007). 30 Feb. $2008<w w w . f o r e i g n a f f a i r s . o r g>$. 